\title{
Where do Good Girls Have Sex? Space, Risk and Respectability in Chennai
}

\section{Sneha Krishnan}

School of Geography and the Environment, University of Oxford, Oxford, UK

South Parks Road, Oxford OX13QY, Sneha.krishnan@ouce.ox.ac.uk

Sneha Krishnan is Associate Professor in Human Geography at the University of Oxford. She is interested in how histories of colonialism and imperial afterlives shape experiences of childhood and youth. She is currently writing a book about women's hostels in Southern India, and has ongoing projects on childhood and geopolitics, as well as on gender and archival practice.

Accepted 19/4/2020 for publication in Gender, Place and Culture. 


\section{Where do Good Girls Have Sex? Space, Risk and Respectability in Chennai}

This paper examines discourses about sexual risk and respectability in the South Indian city of Chennai, through an ethnographic study of young women's participation in practices of public sex. Focusing on middle-class women located at the heart of neoliberal and national fantasies of the 'good life', it makes two arguments. First: the paper unpacks the ways in which urban publics have been stigmatised as 'unsafe' for respectable women. It demonstrates that in practices of publicly-located sex, young women subvert this. They instead see private and commercial spaces - which have been celebrated as the locus of their liberation - as places of surveillance and discipline. Second: the paper interrogates how spatial governmentalities produce regimes of legitimacy that accrue to particular sexual acts. It argues that what 'counts' as sex is also determined geographically: by where the sex act occurs and what geographies of discipline and imaginaries of risk and respectability it evokes in its location. Both arguments draw attention to the ways in which contemporary discourses about the 'risk' of urban publics evoke the logics of development within which the construct of respectable femininity is located.

Keywords: public sex; gender; development; risk; respectability; India

\section{Introduction}

In an inverse of the common wisdom given to couples displaying affection in public spaces - 'get a room!' - the college-going women I met in Chennai often told me that they preferred to engage in sexual acts in public places. Getting a room - whether in a 
hotel, or in someone's home - was 'risky'. It carried the danger of discovery by a parent, or figure of institutional authority. Malls had CCTV cameras everywhere, as did the hostels - dormitory-style boarding houses - where most students live. In the circumstances, 'the best place for some action' was one of the city's beaches, or a local park. Indeed, in the heat of the afternoon sun in this tropical city - hours during which families were unlikely to visit these spaces - I saw couples meeting for intimate encounters on the city's major beaches, and in its parks. When young women spoke about their boyfriends 'taking [them] to the beach', the implication was of a sexual encounter.

Sex and space intersect in urban India with the increasing visibility of pre-marital romance in the popular media, and in youth cultures of dating and flirtation (Mazzarella 2003, Dwyer 2006, Aengst 2014, Brosius 2017, Bhandari 2017, Patel 2017). Typically seen as phenomena of 'liberalisation' - indicating the shifts in culture, politics and economy from the 1990s towards market-led development - this increased visibility of sex in public has been accompanied by anxieties about young women's increased mobility and growing opportunities for romance outside the bounds of caste-endogamous marriage (Aengst 2014, Radhakrishnan 2011, Lukose 2009, Jeffrey 2010, Donner 2016). This discourse of moral panic has been heightened with the ascendance of Hindu Nationalism in this period (Sarkar 2018, Tyagi and Sen 2020). In this context, sexual agency and consent are important sites of contestation.

Further, trajectories of embourgeoisement in South Asia, having emerged in response to colonial discourse, have tended to reinforce norms of chastity and modesty (de Alwis 1995, Osella and Osella 2000, Ciotti 2010, Khoja-Moolji 2016). In the context of contemporary globalization with neo-colonial tendencies, gender and the family have been deployed in familiar ways to '(remap) the nation's boundaries... around conflicts over the presentation of the purity of women' (Fernandes 2000, 22; see also Tamang 
2002, Hewamanne 2008, Ciotti 2010). In India, the state - including the courts and legislative bodies - participates in this disciplining, enacting multi-scalar governmentalities that draw young women's bodies and affects into the labour of producing national futures (Sunder Rajan 2003, Baxi 2006).

As such, even as dating and pre-marital romantic relationships are coded in popular culture as key to middle-class life, upwardly mobile young women find themselves subject to proliferating networks of surveillance. Here, 'risk' is a slippery term: referring simultaneously to the dangers of sexual violence and to anxieties about women's exercise of sexual agency. The 'risky' places of beaches and public parks are sites of porosity in the networks of surveillance that otherwise envelop these women's lives. In contrast, 'safe' places are sites of surveillance where national and neoliberal visions of futurity are reproduced through the disciplining of women's bodies.

Geographical engagements with acts of sex in public have focused on their potential to disrupt fantasies of urban order (Bell 1997, Brown 2004). Increasingly, a wider scholarship on sex and space suggests that public acts of sex are not necessarily disembedded from or resistant to the structures that police them (Hubbard 2004, Andersson 2012). This scholarship shows that intimacy itself is an apparatus of biopolitical governance and an effect of power (Berlant 1998, Povinelli 2006), and conceptualises sex as participant in assemblages of the urban, the nation-state and of contemporary imperialisms (Smith 2012, Legg 2014, Oswin 2015). Building on this work, I draw on ethnographic research to ask how young women's acts of sexual intimacy in public are indicative of the ways in which 'risk' and 'safety' map geographies of gendered respectability.

Gendered norms of respectability in India were articulated in the context of $19^{\text {th }}$ and $20^{\text {th }}$ century reform movements, which located appropriate sexual desire within 
heterosexual and caste-endogamous marriage as well as in the middle-class home (Chatterjee 1989, Sarkar 2001, Hinchy 2014). Scholars of colonial social sanitation have focused on the categorisation and isolation of 'contagious' populations, notably prostitutes (Hodges 2005, Legg 2014). Projects of domestic reform simultaneously cultivated respectable womanhood as the desirable 'other' to this taxonomy of sexual deviance (Mitra 2015). In this, they engaged the Indian home as a site of nationalist selfmaking through home science curricula and the cultivation of modernity in women's hostels run by Indian and Western reformers alike (Sreenivas 2008, Chatterjee 1989, Grewal 1996, Krishnan 2017, Hancock 2001). The ambiguity at the heart of colonial modernity's urban character is noted in the scholarship: cities featured simultaneously as key to the cultivation of modern sensibilities, and as disorderly sites of incomplete modernisation (Legg 2007, Kishore 2015). The trope of the urban college-girl at the threshold of respectability, drawn into disreputable acts by the temptations of the modern city is observable in the popular culture of the early $20^{\text {th }}$ century (Ramamurthy 2006). These views that circulated among educators and policymakers in the colonial period, also seeped into the language of development in postcolonial India (Devika 2006, Ciotti 2010).

These anxieties find contemporary resonance in the context of the social upheavals of the last three decades. My fieldwork in Chennai consisted of a year between May 2012 and April 2013 living in a hostel in the city, followed by visits and interviews every summer (four to six weeks per year) since. In the hostel, I lived in a dormitory with seven others, and these roommates, with whom I conducted long individual interviews, as well as shorter group discussions, became key informants. My research was ethnographic and consisted of participant observation, and semi-structured interviews with individual college-girls and authorities at women's colleges and hostels, as well as 
with groups of students in college and hostel canteens, and in hostel rooms. During follow-up visits, I have conducted interviews with current and former hostel residents. In writing this paper, I have anonymised all research participants, including the institutions.

Most university-going women in Chennai live in hostels. Established from the late $19^{\text {th }}$ century onwards, hostels in Indian cities are key sites where respectable middle-class womanhood is cultivated through rules of dress and behaviour, as well as curfews that restrict young women's access to the city's public spaces. Women's hostels typically do not allow men to visit, and also have rules against visiting the beach or public parks: regulations that speak to the public knowledge of the use of these spaces for sexual activity. In this, these hostels are not unlike the boarding-houses elsewhere in the postcolonial world, where scholars argue that aspirations to respectable middle-class womanhood are routed through discourses of sexual morality (Hewamanne 2008, Demian 2017).

The young women I met were college-students who belonged mostly to the upwardly-mobile 'Other Backward Classes' (OBC): a bureaucratic bracket for castes that are neither high nor Dalit. Southern India has had long-standing affirmative action policies that have allowed members of these castes to gain access to educational institutions (Subramanian 2015). However, students from OBC communities still face discrimination, and narratives about universities being 'swamped' and 'taken over' by a lower caste new middle class are common. College wardens and deans - themselves typically high-caste women - often complained that 'girls from good families', gloss for 'upper caste', now went to Delhi or abroad for higher education. As such, women's colleges in Chennai had growing numbers of 'backward girls'. Anxieties about 'backward' girls and their sexualities justified the proliferation of technologies of surveillance in hostels: in one institution, I counted over a hundred CCTV cameras in 
corridors and facing the open quadrangle, as well as in the canteen and common room. Hostels played a central role in securing middle-class futurity by 'keeping the girls fresh' as one candid hostel Dean put it. Maintaining sexual respectability was key to the work of consolidating middle-class selfhood in the lives of these young women.

'Safe' spaces were thus places that produced non-backward modern and respectable selves through regimes of surveillance. Even as dating and sex are normalised in public culture and form part of the cultural assemblage of middle-class life, engaging in these practices creates precarities in the lives of those whose status as respectable women is not secure. The young women I met were themselves invested in cultivating middle-class womanhood by consolidating their respectability. Engaging in sexual intimacy in public places allowed these young women to slip under the radar of the constant surveillance they endured, while pursuing forms of youthful fun. Indeed, as I learned, keeping secrets is key to the performative inhabitation of respectability and the anonymity of the urban public allowed young women to do this. Simultaneously, by having sex in public places, young women articulated the limits of the intimacies in which they were willing to participate. By not 'getting a room', they refused consent to penetrative intercourse and articulated a hierarchy of sex acts that demonstrated the centrality of the reproductive body to ideas about respectable femininity.

In the remainder of this paper, I begin by setting out the context for my arguments and examining the location of the beach in Chennai within moral governmental imaginaries. The next two sections elaborate this paper's key arguments. The first is that sex in public allows young women to mark themselves as 'respectable'; and second, that this publicness of permissible sexual intimacy shapes hierarchies of legitimacy that accrue to particular sex acts. In conclusion, the paper returns to the questions of pleasure 
and danger at its heart to ask then how sex in public might rearticulate geographies of risk and respectability in urban India.

\section{Context: Risk, Respectability and the City}

In 2003, Seerani Arangam, a public platform on Chennai's Marina Beach was removed in the dead of the night. Such stealthy changes to the city's façade are not uncommon, and other monuments - such as the statue of Kannagi, the mythic paragon of Tamil womanly virtue - have been the subjects of such moves (Pandian 2005). One explanation that was popularly discernible through all this, though it did not make it into the official discourse, was that the demolition had to do with the couples who used Seerani Arangam as a space for sexual intimacy. Narratives of anxiety about young people who use spaces like the Seerani Arangam, and the beach itself for sexual activity are popular among Chennai's middle-class residents. A video published by Dinamalar one of the city's most prominent news outlets, shows visitors to the beach complaining that it was no longer possible to bring children to the beach because of the visible presence of 'lovers' (News 2009). The beach, this programme suggests, is no longer accessible to the general public because of some who 'cross the line' in their activities there. This programme specifies that men often bring women here 'without their parents' permission'.

The removal of the Seerani Arangam offers a useful lens through which to unpack the cartographies of power that undergird contemporary anxieties about young women's participation in practices of public sex. It is indicative of a discourse of urban social sanitation, where the 'menacing' presence of lovers threatens to sully the city's public spaces and make them inaccessible to families. The public spaces of Indian cities have long been the target of gentrifying projects of 'forgetting' and cleaning up (Fernandes 2004). While liberalisation and the demand for 'global cities' has brought some of these 
processes into sharp relief (Roy 2009, Appadurai 2000), they have long persisted in the nexus between bourgeois and state investment in projects of urban development and beautification (Véron 2006, Mawdsley 2004, Baviskar 2011). In Chennai’s case, Arabindoo $(2011,2012)$ argues that the Marina beach has been the target of an 'incomplete civilising mission' from the late colonial period (Arabindoo 2011, 383). Echoing the wider scholarship on colonial urbanism in this context, Arabindoo's argument (2011) situates the beach in Chennai at the heart of anxieties about incompletely modern and 'unplannable' cities in the early and mid-twentieth centuries, as well as the crowds that occupied them. Crucially, these arguments chart continuities between the moral and biopolitical project of colonial social sanitation and that of urban 'cleaning up' and greening. The location of sex was key to these debates (Gupta 2001, Hodges 2005); and its position within heterosexual and companionate marriage was rendered key to the construction of modern and respectable womanhood (Sreenivas 2008).

In this context, questions about where young women could be allowed to go and what public spaces respectable women might occupy was widely debated in cities like Chennai in the early twentieth century (Krishnan 2017, Lakshmi 2004). Indeed, the very question of women on beaches was debated in this time as is evident from a lyrical editorial published in the popular weekly Anandha Vikatan, a Tamil publication in the 1920s (Editors October 1926). In this, the writer warns the magazine's presumably male readership of the seemingly respectable women who sit 'with their legs spread in the direction of the sea'. This imagination constructs these places as being 'out-of-the-way' - marginal locations, literally on the edges both of the physical city, as well as of the order and discipline that is imagined to characterise urban life: places where 'the instability of political meanings is easy to see' (Tsing 1993, 27). Simultaneously, the Anandha Vikatan editorial is indicative of the anxiety about figures of sexual deviance that haunted the 
project of respectable middle-class womanhood. Durba Mitra (2015) argues that the emergence of a sociology of sexuality in India in the $19^{\text {th }}$ and $20^{\text {th }}$ centuries centred on the prostitute as a catch-all figure for anxieties about sexual 'backwardness' that attended reformist modernisation projects (Hodges 2005). Places, like beaches, have long been sites where this project of social sanitation visibly failed (Arabindoo 2011): opening up potentials for playful subversions that engaged these tropes of disrepute, and embrace 'risk'.

The Dinamalar broadcast also suggests that the pervasive anxiety about sexual violence against women precludes narratives of consensual pleasure or casts them as being along a continuum of illegitimacy along with rape. Elsewhere I have suggested that consent is a category fraught with caste, and community concerns for women's chastity (Krishnan 2016). 'Rape' often refers to any sexual activity outside the sphere of community-mediated consent, positioning sexual activity outside marriage in alwaysprecarious light. Concerns about adult women being brought to the beach 'without their parents' permission' thus indicate links between discourses of risk in public spaces, and anxieties about young women's exercise of sexual consent outside the bounds of familysanctioned marriage. This highlights young unmarried women's infantilisation in the practice of the state (Sunder Rajan 2003). The cleaning up of spaces is then purported to safeguard women, even if from their own desires. Consent is regulated here by a carceral regime in which young women 'out of bounds' set off the alarms for risk. This language of 'boundary crossing' is reminiscent of the classic Mary Douglas (2003) conception of 'risk' as located in a potential for 'pollution', and indeed here the 'menace' at hand, is the risk of putting out of orderly place, both 'good' middle class and upper or middle caste women, as well as intimacy itself. The language of 'spoiling' and 'ruination' that typically accompanies popular commentary on young women engaging in sexual activities before 
marriage gives credence to this. 'She spoilt herself' or 'she ruined her life' were often metaphors for women having had sex outside marriage.

The much-feared disorder of the city's public spaces then makes places for 'disorderly' conduct of many kinds for young women: public places, while often removing women from the protections of respectability, free them up for choosing to undertake 'risky' behaviour. The prevalence of public sex in places, like beaches and parks, contests the popular argument that privately-owned and securitized places of consumption are the locus of middle-class Indian women's much celebrated sexual unshackling. Malls and gated living facilities are celebrated in the mainstream media as sites of women's sexual liberation, and attacked by right wing groups for the same reasons: sometimes literally, as in the 2009 assault on women at a bar in the city of Mangalore in Karnataka (Kapur 2012, Dutta and Sircar 2013). In this popular perception, public spaces peopled with working class, lower caste and rural-migrant men, are imagined as threats to urban women's hard-won sexual liberation (Phadke et al 2011).

The young women with whom I spoke regarded many of these private or semiprivate spaces as places of surveillance, where 'nothing is possible' owing either to the presence of middle-class families, security guards charged with maintaining respectability in establishments and evicting anyone who is acting 'obscene'. Instead, despite the occasional vigilante raids and attempts to 'clean up' public parks, young women preferred to engage in intimate practices in these spaces. The absence of CCTV cameras in parks and on the beach was particularly crucial to many. While this is, on the one hand, evidence of the porous nature of policing practices, it was driven by young women's own investment in an ethic of respectability in accordance with which, they saw acts that happened in public parks and beaches as 'silly' and 'fun' but not seriously disreputable. On the other hand, 'getting a room' with a partner suggested a sexual 
transgression that would leave a trace: a brazen act that unsettled the status of sex out of bounds as a public secret. The next section examines geographies of secrecy and visibility on which the dangers of 'getting a room' revolve. I argue that locating intimate acts in public places allows young women to mark themselves as respectable, while also articulating limits to their sexual consent.

\section{Get a Room!}

'Get a Room!' I'd hear in malls when girls leant into their boyfriends' arms in front of friends, and when young men wrapped their arms around girlfriends in the cinema, or the theatre. However, in Chennai, getting a room is a complicated matter. The hostels where young women tend to live as college-students in cities like Chennai act in loco parentis in their lives, justifying carceral discipline as essential to women who are seen as too immature and likely to jeopardise their futures, and crucially their roles in reproducing national futurity. In enacting these forms of surveillance, hostels, as well as commercial establishments, like hotels, malls and cafes, establish themselves as 'respectable' locations.

In my first month in the city, this question came up when a lecturer at a college lost her job after she was found leaving a hotel with her boyfriend one morning, presumably having spent the night there with him. The college's justification was that she was contractually obliged to abide by the institution's rules, including setting a good moral example and upholding the college's reputation. Students at the college thought she had been a bit stupid: it never worked to leave the hotel in the morning with your boyfriend. You had to leave in the middle of the day, with a woman friend to make it seem less suspicious. More significantly, this was why it did not do to get a hotel room: however much more comfortable that might be than furtive groping on the beach. It was 
traceable: you often had to show some kind of ID, of which the hotel would make a copy to keep on file. And then there was the matter of entering and leaving without being noticed. It simply was not 'safe'.

Hotels and other commercial establishments including restaurants and bars often participate in this moral governance. Many hotels have a policy that allows them to inform residents' families, colleges or workplaces if they suspected use of their premises for a sexual encounter outside of marriage. Indeed, several hotels required proof of marriage from couples seeking to stay in a room together. Similarly, elevator operators and security guards at malls and coffee shops frequently intervened when couples showed physical affection to each other. Sometimes, this too could lead to being asked for an ID card. College deans told me that they received several such calls from hotels, mallmanagers and cafes about students behaving 'badly'. Such students were typically expelled or suspended.

'Getting a room' was a matter of visibility. It was 'shameless' as one of the college-girls I got to know during my ethnography put it, 'like you aren’t even trying to hide it.' What happened in the room mattered very little. One young woman cited a popular Tamil proverb to me when I asked her about this: 'if you sit under a palm tree, even the milk you drink looks like toddy.' Referring to the tapping of toddy from Palmyra trees in South India, the saying suggests that appearances are central to reputation. 'Getting a room' brings acts of sexual exploration out of the realm of play and threatens the serious business of reproducing respectable middle-class life.

Appearances - often incommensurate with messy reality - have been shown elsewhere to be integral to the making of respectable womanhood in South Asia (Ruwanpura 2011, Hewamanne 2008, Mookherjee 2006, Baxi 2014). The young women I met saw secret-keeping as an essential skill to 'growing up' and transitioning from 
adolescence to womanhood. Through the keeping of secrets, it was possible to leave some experiences behind in a fantasy-world of childhood, without endangering their reputations. Risk surfaces here in the transaction between secrecy and publicness through which respectability is precariously produced. Secrecies are thus often central to young women's ability to 'play a bit' when they are away from family surveillance and living in an urban hostel in order to attend college. Close knit circles of friends covered for each other, keeping secrets from college authorities, other senior women students as well as men from the young woman's community or district.

Additionally, secrecy is also embroiled in a politics of appropriate knowledge: i.e. what 'good girls' ought to be ignorant of. For instance, in encounters with hostel authorities, the common sense ran among my roommates that it was best to "pretend to be a baby', i.e. to show as little knowledge as possible of acts that might be construed as 'disreputable.' Suggesting the broader stakes of such a politics of sexual knowledge, Pratiksha Baxi (2014) has shown that women's admission to knowledge about sex is often used to delegitimise their claims as 'good' victims of sexual assault in the Indian courts. In the everyday context of a Sri Lankan university - closer to this paper's concern Eshani Ruwanpura (2011) draws attention to the significance of feigning ignorance of sexual matters to the construction of respectability. This then raises the question of the consequences of sexual consent - given with full understanding of the acts in which they are about to engage - for young women. While a great deal of attention is routinely focused on the circumstances in which young women can say 'no' to sex, choosing to say 'yes' is far from uncomplicated. Within this context, the place where 'good' girls might have sex gains importance as a site where young women negotiate the terms of respectable young womanhood. 
It might be noted here that young women do occasionally engage in acts of sexual intimacy with each other in hostel rooms. However, owing both to the fact that most hostel rooms are dormitories of four or more residents, and anxiety about 'lesbians' in hostels, these acts were always framed as playful: testing the boundaries of heterosexuality, only to always reiterate it (Krishnan 2016). The playful enactment of same-sex desire among men has been widely explored both in late-colonial and contemporary South Asia (Katyal 2013, Khanna 2009, Ruwanpura 2011). While similar acts between women are less studied, scholars like Kamran Ali (2004) - writing on Pakistan - suggest that the absence of vocabularies around women's same-sex desire might be understood through a shared common-sense about metaphors and experiences within families of same-sex eroticism albeit as something that is never explicitly spoken or named. Indeed, this would advance the argument made earlier in this section that respectability is constructed by rendering some acts unnameable and untraceable.

Only one young woman I met identified as same-sex desiring, said she did not participate in these playful practices, mostly out of the fear that her very real desire for other women would be discovered in the process. 'Getting caught' in these acts could have serious consequences as well and to prevent such acts, many hostels now require desks between individual single beds. The pervasive anxiety about being perceived as a 'lesbian' meant that young women policed each other: holding the boundary of play intact. As I learned to ask, then, what was 'sex'? And what geographies of respectability and legitimacy accrued to ideas about what counted as sexual activity?

\section{Bases and Places}

In this second part of the paper, I consider the ways in which the body and its sexing are imbricated in an urban geography of risk and respectability. The 'where' of sex, as I 
demonstrate below, speaks not only to the places in which it is possible to give consent to sexual activity without being 'caught' but to how young women's bodies are sexed. Young women's struggle for places in which to pursue (hetero)sexual intimacy reveals hierarchies of legitimacy and transgression in the constitution of the category of the sexual act. In refusing to 'get a room', young women articulate limits to the intimate acts in which they are willing to engage whilst making claims to respectability.

One morning as I got to the canteen at NT College, I saw Shankari perk up and gesture me over. An eighteen-year-old first-year student in computer science, Shankari and I had been talking for some months about her everyday life. She was an 'afternoon college student' - her classes did not begin until 11.30 - but she still came to college at eight in the morning and had told her mother she needed to be in early. This way she got some romantic time on the bus with her boyfriend. Manohar - whose name she said only once, and coyly, otherwise euphemistically calling him 'my him' (ennoda avan) - was her high school sweetheart, and now, to Shankari's pride, an Engineering student in the city. I knew that Shankari had been planning a big moment with Manohar, and as I neared her table, she looked down at her food and said, 'He took me to the beach': a euphemism for what the more outspoken Venetia called 'third base' or oral sex.

Shankari and Manohar had begun their relationship with an exchange of love letters in school, and the exchange of 'I love you' outside the school gates. In time, they had gone to the neighbourhood temple together - here they could pass for being pious and praying for good exam results while finding nooks behind shrines in which to hold hands. Soon Manohar bought Shankari a new mobile phone, one that looked exactly like the phone her father had bought her a few months before, so they could talk all night without fear that they would be discovered when Shankari's parents paid her phone bill, or even checked her calls and texts as they sometimes did. For safety, Shankari had saved 
his number under the name 'Manohari' - the ending suggesting a young woman's name - and used the familiar ' $d i$ ' that women use with each other, to address him on the phone if her parents were present. In other words, they were now in a full-fledged clandestine affair.

'A bomb will break in my house during my marriage' Shankari said to me in English, early into our acquaintance, translating directly from the Malayalam. Though she had been born and raised in a lower middle-class suburb of Chennai, Shankari's family were high-caste Nairs from Kerala. She knew her father would object to her marrying an 'OBC Tamil' man: Manohar belonged to a lower caste and while he was not Dalit, this was still controversial. Indeed, as scholars like Osella and Osella (2000) note, inter-caste marriage in Southern India remains a difficult terrain. In the wider Indian context, for many women the central problem is to make a pre-marital relationship commensurate with the demands of caste-endogamous kinship in marriage: a difficult task that often fails (Donner 2016, Grover 2017). Shankari now saw it as her duty to 'manage' her relationship such that she and Manohar cultivated intimacy and had fun, while the affair remained respectable enough for her to successfully appeal to her parents for permission to marry him in a few years. While Shankari trusted Manohar, she worried that he might see her as 'easy' if she went too far with him. So, in the three years the couple had been together, they had gone from coy letters, to texting messages of love, to kissing in the back of a neighbourhood temple. Now, in 'going to the beach' with Manohar, Shankari had gone as far as she intended to before marriage. 'Going to the beach' allowed Shankari on the one hand to attribute a hierarchy of legitimacy to various sex acts. At the same time, the fact that they did not 'get a room', allowed Shankari to demonstrate her sexual respectability both to her partner, as well as in the future to her parents. If she caused a scandal by being 'caught' at a hotel with Manohar, Shankari was 
sure her family would not allow her to marry Manohar. They would feel he had 'used' her, especially given the difference in caste, and she would not be able to make a case for their marriage. This speaks to the anxiety among higher-caste communities about the growing opportunities for encounter between women of these castes and upwardlymobile lower-caste men. As with the anxiety over 'Love Jihad' (Sarkar 2018), the fear that Dalit and other low-caste men would 'seduce' and alienate from their families women of higher castes is widely prevalent in Southern India (Thiranagama 2019, Srinivasan 2017). In this context, Shankari's decision to 'go to the beach' - and 'be close' to Manohar - whilst refusing to 'get a room' is undergirded by her desire to make a rare success of her inter-caste romance.

Questions about the sex acts to which young women gave consent also had to do with distinguishing themselves - as respectable college-girls - from 'prostitutes'. Earlier in this paper, I argued that the figure of the prostitute lingers as a spectre in the public imagination in India: haunting the project of middle-class respectability (Govindan 2013, Legg 2014, Mitra 2015). As Sunder Rajan (2003) argues, in popular parlance, the accusative naming of 'prostitute' refers not only to women who are sex workers but indicates a site of potential slippage. Women who are perceived as promiscuous and hence undeserving of protection by the state and by their families are equally often accused of being 'prostitutes'. It is telling that when I asked where college girls went to have sex, the answer I most often received was 'no one does that'. A young man I asked where he went for sex sheepishly said, 'Parry's Corner', the red-light district in the city. When I modified this question and asked where one went for some 'action', the answers came pouring: Marina Beach by the swimming pool, the Besant Nagar Beach's far end, Nageshwar Rao Park, and so on. 'Action' I was told, signified the first three 'bases' on the road to sex, in a climactic imagination where 'sex' was only penetrative intercourse. 
Shahana, a twenty-one-year-old resident at the hostel where I lived asked me one evening, 'Who is a prostitute?' I answered that a prostitute was a woman who made a living by performing sex acts for money. She corrected me to say that a prostitute was a woman who had 'no standards' and would 'sleep with any man'. This reinforces the idea that sex workers as well as those regarded promiscuous cannot, by virtue of having given consent to several sex acts and lost respectability, now say 'no' (Sunder Rajan 2003, Govindan 2013). This, Shahana told me, was the reason why she herself had not yet had sex with her boyfriend, even though they had engaged in other forms of intimacy. No man, she told me, would want to marry 'a prostitute': that only happens in films. Shahana's reference to the distinction between films and 'real life' as she put it, is key here. Though sex has come to be more acceptable in films and circulates more visibly in public discourse (Dwyer 2006, Mazzarella 2003), young women like Shahana still do not see this reflected in their own lives. Indeed, even though films increasingly depict young people in sexual relationships, these narratives often circulate as cautionary tales. A 2013 Tamil film, titled Aadhalal Kaadhal Seiveer (Thus, you shall love) was popular among college-girls, who often repeated its premise to me in discussions about sex before marriage. In this film, a young woman who falls pregnant by her college boyfriend faces humiliation from doctors as she attempts to obtain an abortion. Abandoned by her boyfriend, she faces disrepute, and eventually leaves her child in an orphanage. The film - which many young women saw as realistic - emphasises that the stakes are high. Some of my roommates at Theresa Hostel told me that the film's protagonist had been 'stupid'. They believed she could have avoided the risk of pregnancy by refusing 'that relationship' with her boyfriend as many of them did. Indeed, the fact that in the film, the young woman goes to a hotel with her boyfriend was, to many, the first sign that things were likely to go wrong. 
Some, like Arti, whom I met at the hostel where I lived during fieldwork, did not think that they wanted necessarily to wait until marriage for vaginal penetrative sex. She still saw it as a 'special' act that should only occur between people who have 'true love' for each other. Others like Ranjana believed sex would not be pleasurable for the woman unless she was truly in love with her partner. Pain in the act - materialised in the image of bloodied sheets - was romanticised and in a discussion on this in my room at Theresa hostel, my roommates agreed that it connoted vulnerability, the risk of which could only be taken with a husband.

Given that many young women I met drew this distinction, I spoke to a few sex workers in Chennai - women I knew from activist circles, who belonged to organised political groups - about the ways in which 'respectable' women distinguished themselves from 'prostitutes'. Bharani, a forty-two-year-old Aravani - in the more commonly known vocabulary, hijra or member of the third-gender community - laughed when I told her about the euphemism of 'going to the beach': this was, according to her, a phenomenon of 'MTV' as she put it. In the past, Bharani told me, men came to women like her for oral sex because it was an act that 'respectable' women typically refused to perform even on their husbands. However, she told me, with the advent of 'MTV' - from her use of the phrase, this stood in for a range of Western and 'global' cultural influences - she believed that this had changed. Bharani was particularly amused by this shift because, she pointed out, technically, these women were now engaged in an act that could be classed as criminal at the time that I conducted this research. Until September 2018, 'carnal acts, against the order of nature' were criminal according to the Indian Penal Code's section 377: a colonial law that was initially read down to exclude consensual acts in 2009 , and then read back up by the Indian Supreme Court in 2013 before being struck down in 2018. 
Bharani was not wrong. In his December 2013 judgement, Supreme Court Justice Singhvi specified that he was not ruling against any particular community - i.e. the judgement was not to be read as being homophobic - but against a set of acts deemed as being against the order of nature (Singhvi 2013). The text of the judgement suggests that the policing of non-normative sex acts is less about homophobia alone though it certainly entails that, and more about the closing off of the sexual horizon and the re-centring of reproductive, married (typically caste endogamous) heterosexual acts as the only legitimate form of coupling. This hierarchy holds a very different meaning to my informants, most of whom did not believe that they, along with LGBTQ identified people, hijras, and other obviously liminal subjects of the law were liable to classification as 'criminal' on account of their sexual practices. Normative ideals work in contingent ways in creating a sense of precarity. On the one hand, queer and non-heteronormative communities encounter non-reproductive sexual acts as a site of illegitimacy that stigmatises their desires. For the young women I met, on the other hand, the same acts were not so much 'carnal intercourse against the order of nature' - as the now-defunct Section 377 of the Indian Penal Code would have it - but interstitial sites of opportunity. Their acts of public sex were not 'obscene' because they lacked reproductive futurity. Unlike 'getting a room', they did not signal obscenity through the visible breaking of social norms about respectability.

As I demonstrated in the last section, hostels are often sites, where young women engage in same-sex intimacies that they do not see as 'sexual' or at least as 'serious'. As I have argued elsewhere, young women often articulated limits to such exploration: they rarely engaged in sexual activity in private, instead touching each other in performative ways whilst dancing to 'item numbers' or sexually suggestive songs in the hostel room (Krishnan 2016; see also Hewamanne 2008). In speaking to me about such practices, 
young women emphasised that they were 'not lesbo' - i.e. they disclaimed identity as same-sex desiring women. As scholarship on South Asia has shown, such acts often occupy a legitimate place in youth cultures as well as in the everyday messiness of sexual life without coming to be officially inscribed as identity (Ali 2004, Boyce and Khanna 2011, Ruwanpura 2011, Dave 2012,). This refusal to identify themselves as 'lesbo' performed much the same function as the refusal to 'get a room': it left some acts of sexual exploration in the realm of 'fun' where they could not be inscribed into these women's future reputations as they continued to perform the labour of reproducing national and neoliberal futurity. In ascribing a hierarchy of legitimacy to sex acts - the 'where' of the act constituting and constituted by a discourse about the reproductive women's body - young women engaged in a practice of self-making as good middleclass subjects of development.

\section{Conclusion}

Over thirty years ago, Carole Vance (1984) argued that pleasure and danger are engaged in a dialectical relationship in creating the conditions for women's sexual expression. While that argument was made in the specific context of the debates on pornography in American feminism, global stakes for the sex wars are evident in debates on sex work, trafficking, and sexual violence (Shah 2014, Govindan 2013). As Alice Echols $(2016,18)$ notes in revisiting Vance's arguments, assertions of women's right to sexual pleasure particularly outside heterosexual marriage - continue to carry 'the intoxicating whiff of danger' because they transgress norms of 'good womanhood' that are typically seen as deserving of protection. Writing in the Indian context, Rajeswari Sunder Rajan (2003) has argued that for women, successfully demanding protection from the state and from their families depends on their capacity to demonstrate middle-class sexual respectability. 
In other words, 'risk' as a social discourse plays a disciplinary role in women's lives, tethering them to geographies of surveillance, such as that of the home and the home-like spaces of the hostel, as well as to policed commercial spaces, such as malls and cafes. Risk is heightened in the lives of women who are on the threshold of middle-class status: for instance, those who are Dalit or lower caste (Ciotti 2010). For these women, the pressure to perform sexual respectability in the service of producing national and neoliberal futurity is greater.

At the heart of my intervention are questions about the ways in which the disciplinary discourses that undergird the making of ordinary middle-class life as an object of fantasy in urban India shape the conditions under which young women engage in sexual intimacy. The 'where' of sex is central, in this context, to indicating the ways in which young women playfully seek to slip under the radar of the proliferating networks of surveillance to which they are subject in cities like Chennai. While debates on consent centre the conditions under which women can say 'no' to sex, I have shown in this paper that saying 'yes' to sex is similarly fraught and imbricated with spatialised discourses about risk and respectability. Ironically, it is in public places, like beaches and parks, that young women feel able to consent to sexual intimacy outside of marriage. In doing so, they articulate hierarchies of legitimacy attached to particular sex acts: 'going to the beach' allows young women to 'have fun' whilst articulating limits to consent and claiming respectability. These practices - and their location - are further also instrumental to the construction of heterosexual desire as 'normal' and 'respectable'. This might be contrasted with the scholarship on gay men's claiming of public spaces as sites of sex that shows that the public is queered precisely by its delinking from trajectories of heterosexual futurity (Bell 1997, Brown 2004). In contrast, in the lives of middle-class women in India, the anonymity of public space offers an opportunity for suspension - of 
slipping under the radar briefly and without losing respectability - whilst still engaging in the reproduction of normative heterosexuality.

\section{Acknowledgements}

I am grateful to Kanchana N Ruwanpura, as editor, and to the anonymous reviewers of this paper (especially Reviewer 1) for pushing me to improve the paper's analytical focus. I am also grateful to the following for comments on drafts and discussions that shaped my thinking: Sarah Hodges, Caroline Osella, Nandini Gooptu, Miriam Driessen, Aniruddhan Vasudevan and Anusha Hariharan.

\section{References}

Aengst, Jennifer. 2014. "Adolescent movements: Dating, elopements, and youth policing in Ladakh, India." Ethnos 79 (5):630-649.

Andersson, Johan. 2012. "Heritage discourse and the desexualisation of public space: The "historical restorations” of Bloomsbury's Squares." Antipode 44 (4):1081-1098.

Appadurai, A., 2000. "Spectral housing and urban cleansing: notes on millennial Mumbai." Public Culture, 12(3), pp.627-651.

Arabindoo, Pushpa. 2011. "CCity of sand': stately re-imagination of Marina Beach in Chennai." International Journal of Urban and Regional Research, 35(2): 379401.

Baviskar, Amita. 2011. "Cows, Cars and Cycle-Rickshaws: Bourgeois Environmentalists and the Battle for Delhi's Streets" in Elite and Everyman: The Cultural Politics of the Indian Middle Classes, edited by Amita Baviskar and Raka Ray, New Delhi: Routledge.

Baxi, Pratiksha. 2006. "Habeas Corpus in the realm of love: Litigating marriages of choice in India." Australian Feminist Law Journal, 25(1): 59-78. 
Baxi, Pratiksha. 2014. Public Secrets of Law: Rape Trials in India. New Delhi: Oxford University Press.

Baxi, Pratiksha. 2015. "The Child Bears Witness: Menace, Despair and Hope in a Courtroom." In Wording the World: Veena Das and Scenes of Inheritance, edited by Roma Chatterji, 105 - 127. New York: Fordham University Press.

Bell, David. 1997. "One handed geographies: An archaeology of public sex." In Queers in Space: Communities, Public Places, Sites of Resistance, edited by G.B. Ingram, A.M. Bouthillette and Y. Retter. Seattle: Bay Press.

Berlant, Lauren. 1998. "Intimacy: A special issue." Critical Inquiry 24 (2): 281-288.

Bhandari, Parul. 2017. "Pre-marital Relationships and the Family in Modern India." South Asia Multidisciplinary Academic Journal 16. Online since 31 August 2017. DOI:https://doi.org/10.4000/samaj.4379.

Boyce, Paul and Akshay Khanna. 2011. "Rights and representations: Querying the maleto-male sexual subject in India." Culture, Health \& Sexuality, 13(1): 89-100.

Brosius, Christiane. 2017. "Regulating Access and Mobility of Single Women in a "World Class"-city: Gender and Inequality in Delhi, India." In Inequalities in Creative Cities: Issues, Approaches, Comparisons edited by Ulrike Gerhard, Michael Hoelscher and David Wilson, 239-260. New York: Palgrave Macmillan US.

Brown, Gavin. 2004. "Sites of public (homo)sex and the carnivalesque spaces of reclaim the streets." In The Emancipatory City?: Paradoxes and Possibilities, edited by Loretta Lees, 91 - 107. London: SAGE Publications.

Chatterjee, Partha. 1989. "Colonialism, nationalism, and colonialized women: The contest in India." American Ethnologist, 16(4): 622-633. 
Ciotti, Manuela. 2010. "The Bourgeois Woman and the Half-Naked One': Or the Indian Nation's Contradictions Personified." Modern Asian Studies 44 (4): 785-815.

Dave, Naisargi N. 2011. "Indian and lesbian and what came next: Affect, commensuration, and queer emergences." American Ethnologist 38 (4): 650-665.

De Alwis, Malathi. 1995. "Gender, Politics, and the 'Respectable Lady,"' in Unmaking the Nation: The Politics of Identity and History in Modem Sri Lanka, edited by Pradeep Jeganathan and Qadri Ismail, 138 - 156. Colombo: Social Scientists' Association.

Demian, M., 2017. "Making women in the city: notes from a Port Moresby boarding house." Signs: Journal of Women in Culture and Society, 42(2): 403-425.

Devika, Jayakumari. 2006. “Negotiating Women's Social Space: Public Debates on Gender in Early-Modern Kerala, India.” Inter-Asia Cultural Studies, 7 (1): 43-61

Donner, Henrike. 2016. "Doing it our Way: Love and marriage in Kolkata middle-class families." Modern Asian Studies, 50(4): 1147-1189.

Douglas, Mary. 2003. Purity and danger: An analysis of concepts of Pollution and Taboo. London: Routledge.

Dutta, Debolina, and Oishik Sircar. 2013. "India's Winter of Discontent: Some Feminist Dilemmas in the Wake of a Rape." Feminist Studies 39 (1): 293-306.

Dwyer, Rachel. 2006. "Kiss or Tell? Declaring Love in Hindi Films." In Love in South Asia: A Cultural History, edited by Francesca Orsini, 289-302. Cambridge: Cambridge University Press.

Echols, Alice. 2016. "Retrospective: Tangled up in pleasure and danger.” Signs: Journal of Women in Culture and Society, 42(1): 11-22.

Fernandes, Leela. 2000. "Nationalizing "the global"”: Media images, cultural politics and the middle-class in India”. Media, Culture and Society, 22 (5): 611-628. 
Fernandes, Leela. 2004. "The politics of forgetting: Class politics, state power and the restructuring of urban space in India." Urban studies, 41(12), 2415-2430.

Govindan, Padma. 2013. "Rethinking Emancipation: The Rhetorics of Slavery and Politics of Freedom in Anti-Trafficking Work in India." Interventions, 15(4): 511-529.

Grewal, Inderpal. 1996. Home and harem: Nation, Gender, Empire, and the Cultures of Travel. London: Leicester University Press.

Grover, Shalini. 2017. Marriage, love, caste and kinship support: Lived experiences of the urban poor in India. London: Routledge.

Gupta, Charu. 2001. Sexuality, Obscenity and Community: Women, Muslims, and the Hindu Public in Colonial India. New Delhi: Permanent Black.

Hancock, Mary. 2001. "Home science and the nationalization of domesticity in colonial India.” Modern Asian Studies, 35(4): 871-903.

Hewamanne, Sandya. 2011. Stitching identities in a free trade zone: Gender and politics in Sri Lanka. Philadelphia: University of Pennsylvania Press.

Hinchy, Jessica. 2014. "Obscenity, moral contagion and masculinity: Hijras in public space in colonial North India." Asian Studies Review, 38(2): 274-294.

Hodges, Sarah. 2005. "'Looting' the Lock Hospital in Colonial Madras during the Famine Years of the 1870s." Social History of Medicine 18 (3): 379-398.

Hubbard, Phil. 2004. "Revenge and Injustice in the Neoliberal City: Uncovering Masculinist Agendas." Antipode 36 (4):665-686.

Kapadia, Karin. 1995. Siva and her Sisters: Gender, Caste, and Class in Rural South India. Colorado: Westview Press.

Kapur, Ratna. 2012. "Pink chaddis and SlutWalk couture: The postcolonial politics of feminism lite." Feminist Legal Studies 20 (1):1-20. 
Katyal, Akhil. 2013. "Laundebaazi: Habits and Politics in North India." Interventions, 15(4): 474-493.

Khanna, Akshay. 2009. "Taming of the Shrewd Meyeli Chhele: A political economy of development's sexual subject." Development 52 (1):43-51.

Khoja-Moolji, Shenila. 2018. Forging the ideal educated girl: The production of desirable subjects in Muslim South Asia. Oakland, CA: University of California Press.

Kishore, Raghav. 2015. “Urban 'failures': municipal governance, planning and power in colonial Delhi, 1863-1910." The Indian Economic \& Social History Review, 52(4): 439-461.

Krishnan, Sneha. 2017. “Anxious Notes on College Life: The Gossipy Journals of Eleanor McDougall." Journal of the Royal Asiatic Society, 27(4): 575-589.

Krishnan, Sneha. 2016. "Agency, intimacy, and rape jokes: an ethnographic study of young women and sexual risk in Chennai." Journal of the Royal Anthropological Institute, 22(1): 67-83.

Lakshmi, CS. 2004. "Introduction: Notes on Chennai" in The Unhurried City: Writings on Chennai, edited by CS Lakshmi, ix - 1xii. New Delhi, Penguin.

Legg, Stephen. 2007. Spaces of Colonialism: Delhi's Urban Governmentalities. Oxford: Wiley Blackwell.

Legg, Stephen. 2014. Prostitution and the Ends of Empire: Scale, Governmentalities, and Interwar India. Durham, NC: Duke University Press.

Lukose, Ritty. 2005. "Consuming globalization: Youth and gender in Kerala, India." Journal of Social History 38 (4): 915-935.

Mawdsley, Emma. 2004. "India's middle classes and the environment." Development and Change, 35(1): 79-103. 
Mazzarella, William. 2003. Shoveling Smoke: Advertising and Globalization in Contemporary India. Durham, NC: Duke University Press.

Mookherjee, Nayanika. 2006. “'Remembering to forget': public secrecy and memory of sexual violence in the Bangladesh war of 1971." Journal of the Royal Anthropological Institute, 12(2): 433-450.

News, Dinamalar. 2009. Beach Love. Dinamalar.

Osella, Caroline, and Filippo Osella. 2000. Social Mobility in Kerala: Modernity and Identity in Conflict. London: Pluto Books

Oswin, Natalie. 2015. "World, city, queer." Antipode 47 (3):557-565.

Pandian, M. S. S. 2005. "Void and memory: story of a statue on Chennai beachfront." Inter-Asia Cultural Studies 6 (3): 428-431.

Patel, Viresh. 2017. "Parents, permission, and possibility: Young women, college, and imagined futures in Gujarat, India." 80:39-48.

Phadke, Shilpa, Sameera Khan, and Shilpa Ranade. 2011. Why Loiter? Women and Risk on Mumbai Streets. New Delhi: Penguin Books.

Povinelli, Elizabeth A. 2006. The Empire of Love: Toward a Theory of Intimacy, Genealogy, and Carnality. Durham, NC: Duke University Press.

Radhakrishnan, Smitha. 2011. Appropriately Indian: gender and culture in a new transnational class. Durham, NC: Duke University Press.

Ramamurthy, Priti. 2006. "The modern girl in India in the interwar years: Interracial intimacies, international competition, and historical eclipsing." Women's Studies Quarterly, 34(1/2): 197-226.

Roy, Ananya. 2009. "Why India cannot plan its cities: Informality, insurgence and the idiom of urbanization." Planning theory, 8(1):76-87. 
Ruwanpura, Eshani. 2011. "Sex or Sensibility? The making of chaste women and promiscuous men in a Sri Lankan university setting”. PhD Dissertation, University of Edinburgh and Queen Margaret University.

Sarkar, T. 2018. Special Guest Contribution: “Is love without borders possible?" Feminist Review, 119(1): 7-19.

Sarkar, Tanika. 2001. Hindu Wife, Hindu Nation: Community, Religion, and Cultural Nationalism. London: Hurst.

Shah, Svati P. 2014. Street corner secrets: Sex, work, and migration in the city of Mumbai. Durham, NC: Duke University Press.

Singhvi, G.S. 2013. Suresh Kumar Koushal \& Anr vs Naz Foundation \& Others. In Civil Appeal No.10972 of 2013, edited by Supreme Court of India. New Delhi.

Smith, Sara. 2012. "Intimate geopolitics: Religion, marriage, and reproductive bodies in Leh, Ladakh." Annals of the Association of American Geographers 102 (6):15111528.

Sreenivas, Mytheli. 2008. Wives, Widows, and Concubines: The Conjugal Family Ideal in Colonial India. Bloomington: Indiana University Press.

Srinivasan, Perundevi. 2017. Love Meets Death: "Honour," Violence, and Inter-caste Marriages in Tamil Nadu (Working Papers of the Chicago Tamil Forum, Volume 3). Chicago: University of Chicago Tamil Forum. Retrieved from http://chicagotamilforum.uchicago.edu/workshops/2016/ewExternalFiles/Perund evi\%2C\%20S_Love\%20Meets\%20Death\%20\%28CTF\%2C\%202016\%29.pdf.

Sunder Rajan, Rajeswari. 2003. The Scandal of the State: Women, Law, Citizenship in Postcolonial India, Next wave. Durham, NC: Duke University Press.

Tamang, Seira. 2002. "Dis-embedding the sexual/social contract: Citizenship and gender in Nepal." Citizenship Studies, 6(3): 309-324. 
The Editors. 1926. "A Lyrical Editorial." Anandha Vikatan. October Edition. No page Numbers.

Thiranagama, S. 2019. "Respect Your Neighbor as Yourself: Neighborliness, Caste, and Community in South India.” Comparative Studies in Society and History, 61(2): 269-300.

Tsing, Anna Lowenhaupt. 1993. In the Realm of the Diamond Queen: Marginality in an Out-of-the-way Place. Princeton: Princeton University Press.

Tyagi, Aastha and and Atreyee Sen (2020). "Love-Jihad (Muslim Sexual Seduction) and ched-chad (sexual harassment): Hindu nationalist discourses and the Ideal/deviant urban citizen in India." Gender, Place \& Culture 27(1): 104-125.

Vance, Carole. 1984. "Pleasure and Danger: Towards a Politics of Sexuality" in Pleasure and Danger: Exploring Female Sexuality edited by Carole Vance, 1 - 28. London: Routledge.

Véron, René. 2006. "Remaking Urban Environments: The Political Ecology of Air Pollution in Delhi." Environment and Planning A: Economy and Space. 38(11): 2093-2109. 